\title{
知識工学の応用による海洋情報の抽出 \\ Extraction of Ocean Conditions by Applying Knowledge Engineering Method
}

\author{
舆 石 肇*, 山本 浩道** \\ Hajime KOSHIISHI, Hiromichi YAMAMOTO
}

\section{1.はじめに一研究の動機}

地球観測データからの情報の抽出には，少なくとも その最終段階ではユーザの専門的知識を必要とする。 例えば，漁場についての情報を提供する漁海況速報図 から情報を得るにも専門的知識を必要とするが，この 漁海況速報図を海面温度図から作成するには非常に高 度の専門的知識と経験と勘とを必要とする。この様な 情報抽出システムを人工的な情報処理システムとして 構築することは殆ど不可能であるが，僅かにその可能 性を与えるのが知識工学である。

人工衛星による遠隔観測技術でこの漁海況情報を抽 出するために知識工学を使って情報抽出システムを構 築して見たいと思うようになったのは，スペースス テーションの上にリアルタイムで海洋情報を抽出し伝 送するシステムを構築することを思い立ち，そのシス テムスタディーを始めてからである。この様なシステ ムでは非常に高速に, 殆ど自動的に海洋情報の抽出が 行われなければリアルタイム性など成立たない。そこ で専門家はこの海洋情報の抽出をどの様にしてやって いるのかの調査が始まり，そこへ知識工学を援用しよ うということになったのである。スペースステーショ ンのシステムはその先見性や有用性，技術的面白さが 世に理解されず今のところ停滞しているが, 多少の研 究費と漁業情報サービスセンターの御協力が得られた ので，漁海況情報抽出への知識工学の援用についてだ けは幾らかの進展を見ることが出来た。以下にその概 要を紹介する。

*(財リモート・センシング技術センター

**航空宇宙技術研究所

「写真測量とリモートセンシング」Vol. 30, No.4，1991

\section{2.なぜ知識工学が必要か。}

知識工学は, 従来の情報処理手法では複雑過ぎてシ ステム化が困難な問題を対象とし，一般化した問題と してでなく，特定の具体的問題を対象とする。そして 今までは到底解決困難で取組む意欲も起きなかった問 題にも, 専門家一知識工学者という組合せで挑戦した くさせる。画像処理技術と知識工学を使い, 海洋情報 の解析・海洋現象の予測を行おうというのも，その一 つである。

知識工学での知識の表現には，事実や判断規則を一 つ一つ宣言として表現する謂わば，宣言的表現と，特 定の問題を解決する方法を一連の行動の手続きとして 表現する，手続的表現とに大別される。宣言的表現の 特徵は, 知識が互いに独立なものとして表現でき, 地 域の追加・修正が比較的容易な点である。これに対し FORTRAN 言語や COBOL 言語は典型的な手続的表 現である。知識工学では，基本的には宣言的表現をモ ジュールとして多数集積し，それらを推論機構により 組合わせて問題の解決に当る。

宣言的表現を推論機構により組合わせる方法には, IF- THEN 形式でルールを表現する“プロダクショ ン・システム”，フレームと呼ばれる知識表現単位で表 す“フレーム・システム”等を始めとし多くの方式が 研究されている。また推論の方式についても“前向き 推論” “後向き推論”の研究も活発であり，ともに幾多 の研究がなされている。

さて，この様な知識工学が具体的分野に応用される ときの方法論の典型がエキスパート・システムである。 エキスパート・システムは，ある領域の問題に対して 人間の専門家と同等の能力を有するような知識型シス テムを指し，次の様なシステムとして定義される。即 ち, “人間の知性を用いなければ解けないような特定分 
野の問題を解決するのに, 専門家の知識をコンピュー 夕に組込んで，人間に代って或いは人間を支援して問 題解決を行なうことを目的としたコンピュータ・シス テム”をいう。実際には上述の知識ベースと推論機構 により問題解決を図るシステムであり, 処理アルゴリ ズムが存在しない或いは明確でない問題, 条件の組合 せ数が膨大で逐一判断処理が行ない難い問題などに適 している。換言すれば，エキスパート・システムの対 象分野は, 問題の構造が不明確な悪構造 (Ill- Structured）問題であり，同時に問題自体を明確に規定するこ とが難しい悪定義(I11- Defined) 問題である。

ここで言う悪構造な問題とは, 従来の定型型業務の ように決定的な処理手順で表現することが難しく, 非 決定的な処理にならざるを得ない問題のことである。 また, 覀定義な問題とは, 対象とする範囲や問題解決 のためにどのような回答を出せば良いか等が開発当初 に於いて明確に定義付けることが困難な問題のことで ある。エキスパート・システムは謂わば, 従来の技術 では不得意なこのような技術分野をその対象とするこ とが出来る。このことから, その適用領域は医療診断 から為替予測まで極めて広い。

エキスパート・システムの開発で従来型のシステム 開発と異なる困難な点は知識の抽出に関わる問題であ る。ここで対象としている, 漁業を始めとする水産活 動に重要な漁海況速報図の作成を支援するシステムへ の適応を考えてみると, 先ず現行システムでの作業状 況の分析が重要である。NOAA 衛星の高感度赤外放射 計（AVHRR）のデー夕を基に海面温度図が作られ， 専門家はこれを目視しながら潮境・海流・渦・湧昇流 等の海洋情報, 更には, 海況と漁場に関する専門知識 を基に何処にどのような漁場が形成されているかを推 定して漁業情報等を書込む。エキスパート・システム 構築のためには, このような専門家が行なう各作業過 程での知識と判断を整理してコンピュータに組み込む ようにしなければならない。これらの過程での知識情 報は, 従来的な情報処理手順に適合し得る形で整理さ れているとは限らないし，むしろ，より多くの対話的 介在を必要とするものが多く, 構造的な明確さにも欠 けている。

このような問題解決に必要な情報, 即ち知識を, 専 門家などの知識源から収集・定式化し，それを知識工 学が提供する手法で取扱える形に変換し, さらに、コ ンピュータで扱えるように構造化する作業が重要であ
る。

このように, 専門家から必要な知識を得ることがエ キスパート・システム開発の必須条件である。また, エキスパート・システムは一度動き出してからも, 知 識の䛊りや矛盾, 或いは知識の増大に対応して, 常に 変更され続けるのが普通である。

\section{3. 漁海況速報図作成の現状}

漁業にとって水温というのは最も重要な環境条件の 一つであり，夫々の魚に適した水温がある。海流の方 向と速度及び渦も漁場を見つけるための重要な要素で ある。人工衛星によるイメージ・デー夕は海流, 渦, 及び潮境などを検出するのに非常に有効である。この ためには先ず海面温度分布図を作らなければならな い。これには, 衛星に搭載された赤外放射計による水 温データと, 船舶で計測された水温データとが用いら れている。

現在, 実験的に運用されているシステムでは, 陸地 と緯度一経度の書込まれた透明な紙を, 上述の水温 データを基にコンピュータで計算され CRT ディスプ レイ上に表示された海面温度罒の上に置き，その上に 専門家が暖水塊, 冷水塊, 渦, 舌状の張り出し, 潮境, 黒潮，親潮などを書込んでいく。この様にして図 1 に 示す様な海況図が出来上る。これに更に，何処にどの 様な魚がいるかと言う情報を書込んだものが漁海況速 報図である。これを作り上げるには，海洋と漁業に関 する専門家の豊富な知識と経験を基にした Trial and Errorの作業, Multi-temporalのイメージ・デー夕そ の他を用いた雲とその大きさの判断等, 非常に多くの 作業を必要とする。

\section{4. 漁海況速報図作成のシステム化}

上述の様に，漁海況速報図作成の現状は非常に多く の時間と労力を要するもので, 将来に向けてはそのプ ロセスをコンピューティング・プロセスとしてシステ ム化し処理時間を短縮し, 処理過程を単純化すること が必要である。その方法として考えられるのが, この 海洋と漁業についての専門家の知識と経験をコン ピューティング・プロセスの中に知識ベースとして取 込んでシステム化することである。そのためには先ず， それら海洋状況の判断に用いられている知識と経験を 


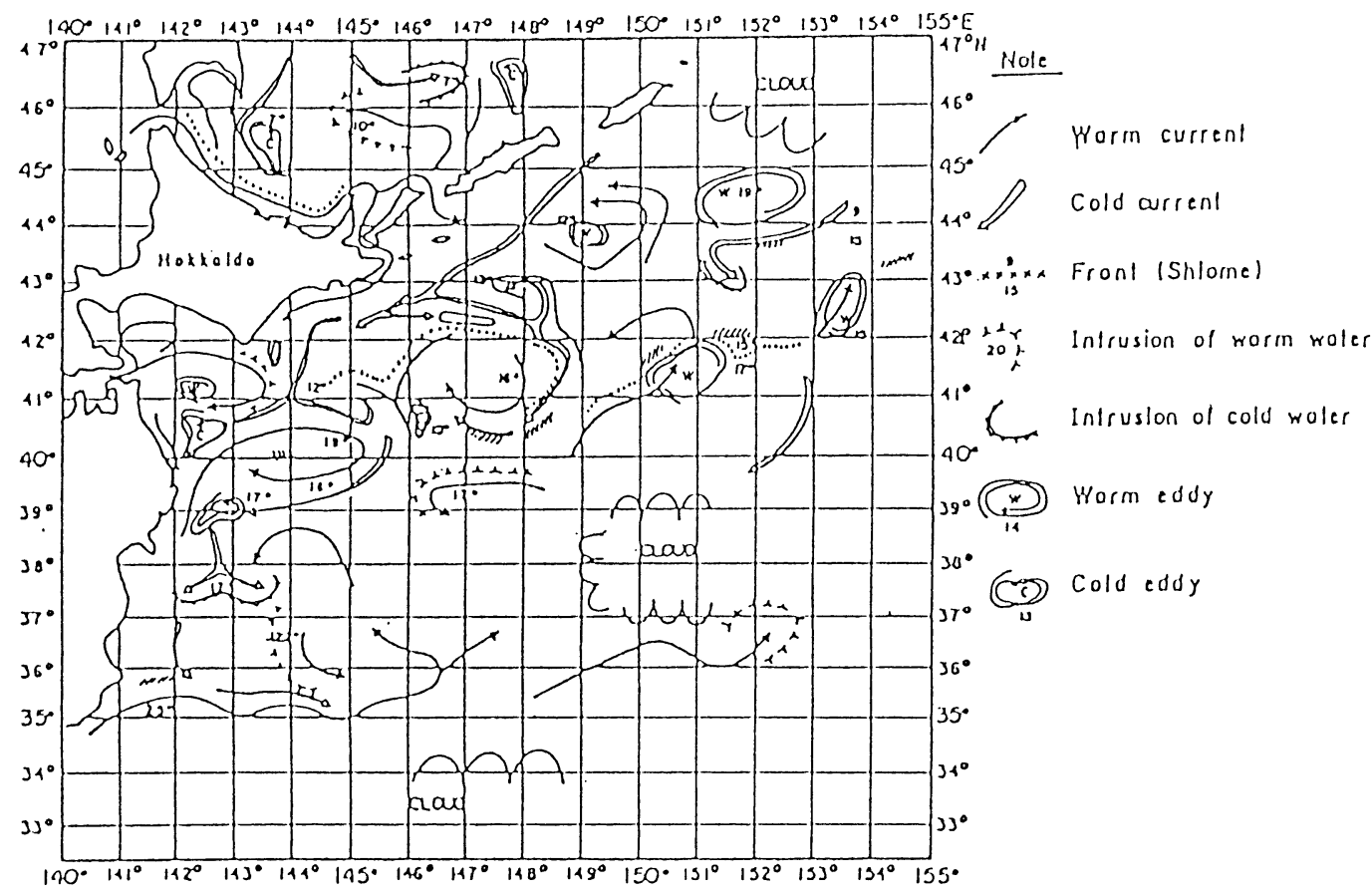

図 1 衛星情報による海況図

\section{表 1 海洋情報抽出のための知識情報}

1。温度差/距離> $\chi$ を潮境とする。

2. $\chi$ は，一般的には各海域で異る。

3 、温度差および距離の選定は, 海域に依存する。

4.距離は, 潮境の法線方向に取る。

5。その現象は，沿岸部より沖合いに多い。

6. 幾つかの潮境が平行して集中することがある。

7。潮境が密に集る所は，温度勾配が大きい。

8.潮境は曲線かつ断続的である。

9 、潮境は交わることはない。

10. 潮境は等温線の方向と一致する。

11. 潮境の発生し易い海域がある。

12. 潮境は大局的には, 南北方向より東西方向に形成 される場合が多い。

分析することが重要である。その分析結果の一部を表 1 に示す。これは潮境の推定に用いられているものの 分析結果をリストアップしたものである。プロセスの システム化の第一段階として，これを含めて約 60 項目 が分析されている。それ等の中には上記以外の海洋に 関する知識・情報, 衛星イメージ・デー夕そのものに 関する情報，海洋情報分析をシステム化するシステム そのものに関する情報などが含まれている。

これらの知識情報の中の一部のものは, 画像処理と
パターン認識のアルゴリズムに対応する様に, 更に細 かい処理プロセスに分解される。また，夫々の情報の 特性に適合するように適性な言語が選ばれる。

\section{5. システム構成}

上述のスタディーとこの様な知識情報アルゴリズム を載せ得る計算機システムに関するフィージビリ ティー・スタディーを基に，海洋と漁業に関する専門 家の知識と経験を組込んで海面温度困から海況情報を 抽出する，知識工学を援用したシステムとして，図 2 の様なシステムを構成した。

このシステムは, 知識データベース, 推論エンジン, 処理手順ベース, 画像解析実行部, 画像処理パッケー ジ, ルールエディ夕, 解析結果画像化機構などから構 成されている。

海洋情報解析のための専門的な知識情報は, 第 2 節 に述べた“IF- THEN”形式のルールとして表され, 画 像処理パッケージを制御するコマンド制御ルール，お よび各処理パッケージで必要なパラメータ設定等に関 するパラメータルールの 2 形式でルール化されてい る。また, 解析対象画像デ一夕の属性や解析条件等は, 


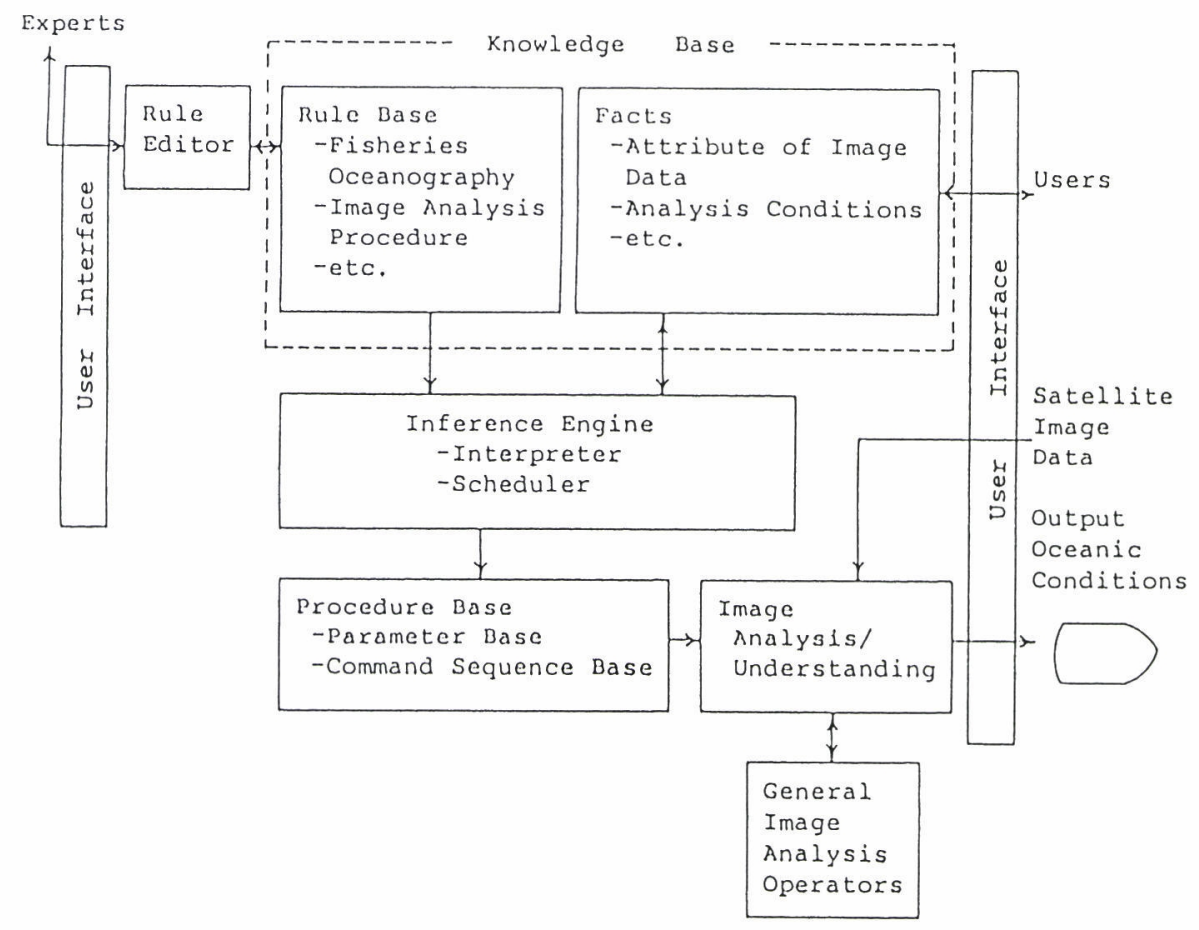

図2 海面温度図解析支援エキスパートシステム

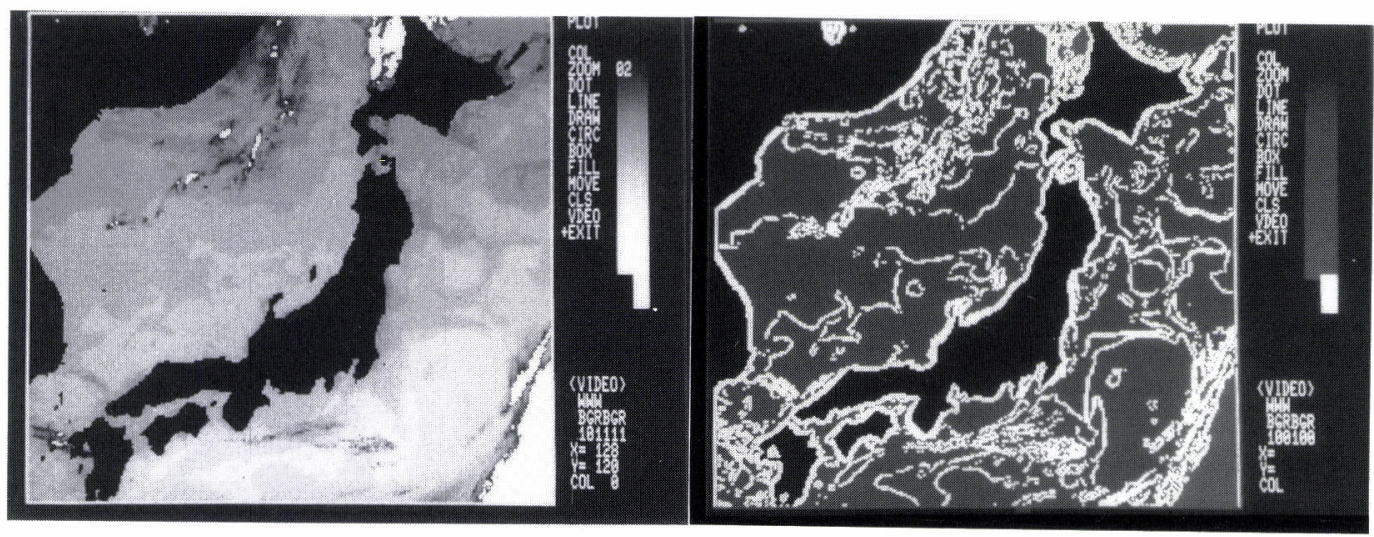

図３エキスパートシステムによる潮境抽出の結果

ファクトとして構成される。これらは, 全てル一ル工 ディタで追加変更が自在な知識ベースとして構成さ れ, 推論エンジンの下で, 画像処理パッケージ群を使 用し, 所要シーケンスの構成・実行を行なう。

また，画像処理関連のソフトウェア開発環境を考慮 して，汎用計算機のオペレーティングシステムの配下 で動作可能とした。知識ベース・推論エンジン, およ びユーザインターフェース部は, Common Lisp で記 述し, 画像解析実行部は, 既存ソフトウェアの有効利
用を図るために，FORTRAN 記述を中心とした画像 処理パッケージを外部ライブラリーとして, 画像デー 夕駆動部, パラメー夕設定空間等とともに汎用画像解 析処理システムとの互換性を図っている。試作システ ムの主要機能は，概ね表 2 に示す如くである。

図 3 にこのシステムによる潮境抽出の実験結果の一 例を示す。この実験では, 大力として NOAA 衛星の赤 外放射計のデー夕から得られた海面温度四が用いられ た。即ち, 日本周辺海域の512 pixel ×512 line の各画素 


\section{表 2 システム主要機能}

○ルールエディタ ルールの追加・削除・表示

○推論・制御年泟作成・実行, パラメー夕設定,

優先順位的ルール競合解消, ルールのセーブ・ロード, 画像処理オペレータの駆動, 画像ファイル登録・削除,

○画像処理 汎用画像処理パッケージ (FORTRAN）の登録

8 bits のデータが処理された。結果はカラーで表示さ れている。

\section{6. 結 論}

この研究で試みられたシステムは，システムの知識 ベースに組込まれた海洋や漁業の専門家の知識と経験 を基に，海面温度図から二次元（海面）の海況情報を 可成りの短時間で抽出することが出来た。
以上のプロトタイプ・システムによるフィージビリ ティー・スタディーに続いて更に進んだ知識工学援用 のシステムの研究が試みられている。そして,さらに 将来の開発段階では, Image Seqence Analysis を用い て，より高精度に海況情報を抽出すると共に，漁場予 報を含んだ海況情報図が効率よく作成される様になる ことが期待される。

\section{参 考 文 献}

1 ) "Conceptional Desingn Study of Real Time Reporting System on Oceanic Conditions" National Aerosp ace Laboratory, NAL SP-2T, 1984

2 ) "A Study on Information Analysys Aids for Sea Surface Temperature Image Data" H. Koshiishi et al, The 16th International Congress of ISPRS, Kyoto, 1988

3 ）“赤外画像からみた渦動の生成・成長と漁場”空と海, 第 8 号, 1986

4 ）“海面温度図解析支援エキスパート・システム”興石 肇 他，第14回リモートセンシングシンポジュウム，計 測制御学会，昭和63年10月 